\title{
Molecules making waves in axon guidance
}

\begin{abstract}
Alfredo Varela-Echavarría and Sarah Guthrie ${ }^{1}$ London SE1 9RT UK

The exquisite complexity of neural connectivity depends upon the precise navigation of axons to their targets in the developing nervous system. How is this achieved? Signals from the environment are assumed to impinge on growth cone receptors and thus steer axons in the right direction, but the molecular details of this process have been largely unknown. Recently, impressive progress has been made in identifying families of molecules that may underlie this process. Candidate diffusible guidance molecules include the netrins and semaphorins, whereas membrane-associated Eph receptors and their ligands are proposed to influence guidance by cellcell contact. Characterization of receptors for some of these molecules now promises the dissection of the signalling pathways that dictate axonal responses to pathfinding cues.
\end{abstract}

Department of Developmental Neurobiology, United Medical and Dental School (UMDS), Guy's Hospital,

\section{Developmental strategies for axon pathfinding}

Since the pioneering work of Ramòn y Cajal in the late 19th and early 20th century, attention has focused on the descriptive characterization of axon pathways in the developing vertebrate embryo. From these studies, a number of principles have emerged. First, structures located along the axon pathways are utilized by axons as intermediate targets. For example, in the vertebrate spinal cord, dorsal commissural axons project to an intermediate target, the ventral midline floor plate, before turning rostrally (Dodd and Jessell 1988). Second, early-growing axons may provide a substratum for the fasciculation of later growing axons, so that the latter may not be required to respond to the guidance systems employed by pioneer axons. Third, axons may reach their target anlage before the migration of the latter to its final location, with tethered growth of the axon ensuring that the connection is maintained during the migration. Such is the case of the interaction of abducens motor axons and their extraocular muscle targets before migration to the eye in the chick embryo (Wahl et al. 1994). Fourth, axon trajectories may be elaborated not only by axon navigation, but by the migration of neuronal somata following axon outgrowth. This is exemplified in the contralateral

\footnotetext{
${ }^{1}$ Corresponding author.
}

E-MAIL s.guthrie@umds.ac.uk; FAX 0171-955-4886. migration of subsets of vestibuloacoustic neurons in the hindbrain. These neurons translocate their somata contralaterally after their axons have projected to the periphery (Simon and Lumsden 1993).

\section{Mechanisms of axon guidance}

Despite the mechanisms described above, that appear to simplify the formidable task of navigation, pioneer axons must nevertheless actively pathfind across embryonic tissues possessing few obvious landmarks. This is especially true of the vertebrate peripheral nervous system (PNS), whereas axons of the central nervous system (CNS) must select appropriate pathways within a field of other developing neurons and axon tracts. In seeking to understand axon guidance, it is useful to define several categories of mechanisms, distinguishing positive and negative mechanisms mediated by local (short-range) or diffusible (long-range) axon guidance molecules (Fig. 1). Depending upon molecules that are membrane-bound or are extracellular matrix (ECM) components, contact-mediated interactions may result in the promotion or the inhibition of axonal growth. This may serve to restrict axons to a pathway by providing a permissive environment for growth flanked by a hostile environment. By contrast with contact-mediated cues, diffusible cues form gradients that originate from distant tissues and specify the direction of axonal growth. For such diffusible molecules, two modes of action can also be distinguished, one that results in chemorepulsion of the growth cone from the source of signal or one that results in chemoattraction towards it. Thus, although nondiffusible molecules might lay out "permitted" axon growth pathways, diffusible molecules might determine the direction of growth within these pathways.

In experiments designed to test the roles of particular molecules, axon growth and axon guidance have sometimes been interpreted at separate phenomena. Prior to the isolation of diffusible molecules that orient axons, chemoattraction and growth promotion sometimes have been considered as activities attributed to separate classes of molecules. Similarly, chemorepulsive molecules have been considered as distinct from those that simply inhibit growth. However, the idea that single molecules might have both properties has gained cur- 


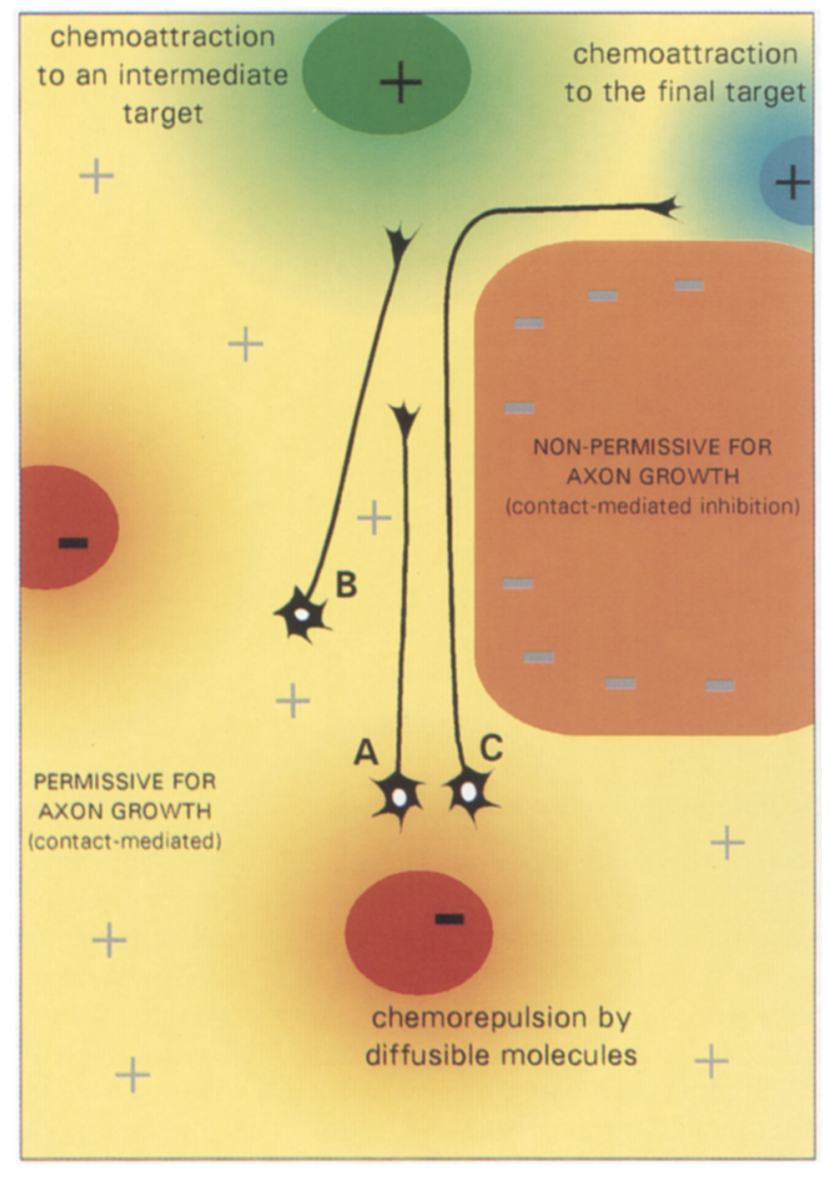

Figure 1. General mechanisms of axon guidance. Growing axons respond to two general types of guidance signals: those that diffuse from their site of synthesis, such as chemoattractants and chemorepellents, and those that are membrane bound or ECM components that are either permissive or nonpermissive for axon growth (contact-mediated). Combinations of these basic types of signals may result in the complex behavior of growing axons, as shown. Chemorepellent signals may act to repel the growing axon from the site of its initial projection $(A)$ or deflect its growth when presented as a lateral signal $(B)$. Chemoattractant cues may attract axons to intermediate targets (green signal) en route to the final targets $\mid C$ and blue signal). Although diffusible signals may determine directionality, nondiffusible signals provide pathways permissive for growth (yellow) and areas that exclude axons (orange). Nondiffusible molecules may also form gradients that control graded termination of different populations of growing axons (not shown).

rency and is emphasised by recent work on families of axon guidance molecules. The manner in which the regulation of growth and the regulation of directionality intersect to guide axons is still poorly understood. For example, a general suppression of growth of retinal axons at the optic chiasm may be involved in modulating axonal reponses to signals that govern decussation in this region (Wang et al. 1996).

\section{Families of axon guidance molecules}

Recently, substantial progress has been made in the iso- lation of axon guidance molecules that perform specific functions in the context of established paradigms (Fig. 2). Prominent among these are the semaphorin and netrin gene families, whose members were implicated primarily as diffusible factors, but whose mode of action is now revealed as more complex and diverse. For example, members of the collapsin-semaphorin family may be secreted or membrane-associated (Kolodkin et al. 1993; Luo et al. 1995), whereas the first chemoattractant to be isolated, netrin-1, has sequence similarity with the ECM protein laminin (Kennedy et al. 1994). Thus these molecules may be implicated in both short- and long-range signalling. Similarly, the distinction between promotion of growth and orientation breaks down when considering that netrin-1 has both of these properties, whereas the diffusible molecule collapsin 1 /semaphorin D/III, initially identified as a molecule causing complete inhibition of growth exemplified by growth cone collapse (Luo et al. 1993), has chemorepellent properties when presented as a focal source in a collagen gel (Messersmith et al. 1995; Püschel et al. 1995). In the context of molecules conventionally supposed to behave as short-range cues, attention has focused on the role of immunoglobulin superfamily members, such as NCAM, L1, and SC1 in axon routing. In addition, the Eph family of receptor tyrosine kinases (RTKs) contains promising candidates in axon navigation, particularly in the context of target recognition. In this review, we consider families of molecules individually and describe some of the experiments that have illuminated their role in vertebrate axon guidance.

\section{Semaphorins}

Semaphorins constitute a family of secreted and membrane proteins with representatives identified in both insects and vertebrates. Their distinctive feature is the 500 amino acid semaphorin domain, characterized by 16 conserved cysteines, which is required for activity but whose specific function is unknown. Semaphorins also contain sequence motifs found in other secreted, transmembrane, or ECM proteins such as immunoglobulinlike and thrombospondin domains. Semaphorins have been grouped in five subclasses that include both transmembrane and secreted proteins (Fig. 2). The first evidence attributing axon guidance properties to semaphorins came from studies in grasshopper that led to the discovery of semaphorin I (sema I, originally called fasciclin IV; Kolodkin et al. 1992). Antibodies against the membrane-bound sema I caused disruption of the normal projection of sensory axons, which suggested a role for this protein in axonal guidance. Earlier in vitro studies had demonstrated the presence of a growth cone collapseinducing activity in embryonic chick brain extracts (Raper and Kapfhammer 1990). Later, Luo et al. (1993), identified a secreted protein, collapsin-1, present in embryonic and adult chick brain, by virtue of its ability to cause growth cone collapse in the same in vitro assay. The sequence of collapsin-1 revealed it as a member of the semaphorin family (Luo et al. 1993; Kolodkin et al. 

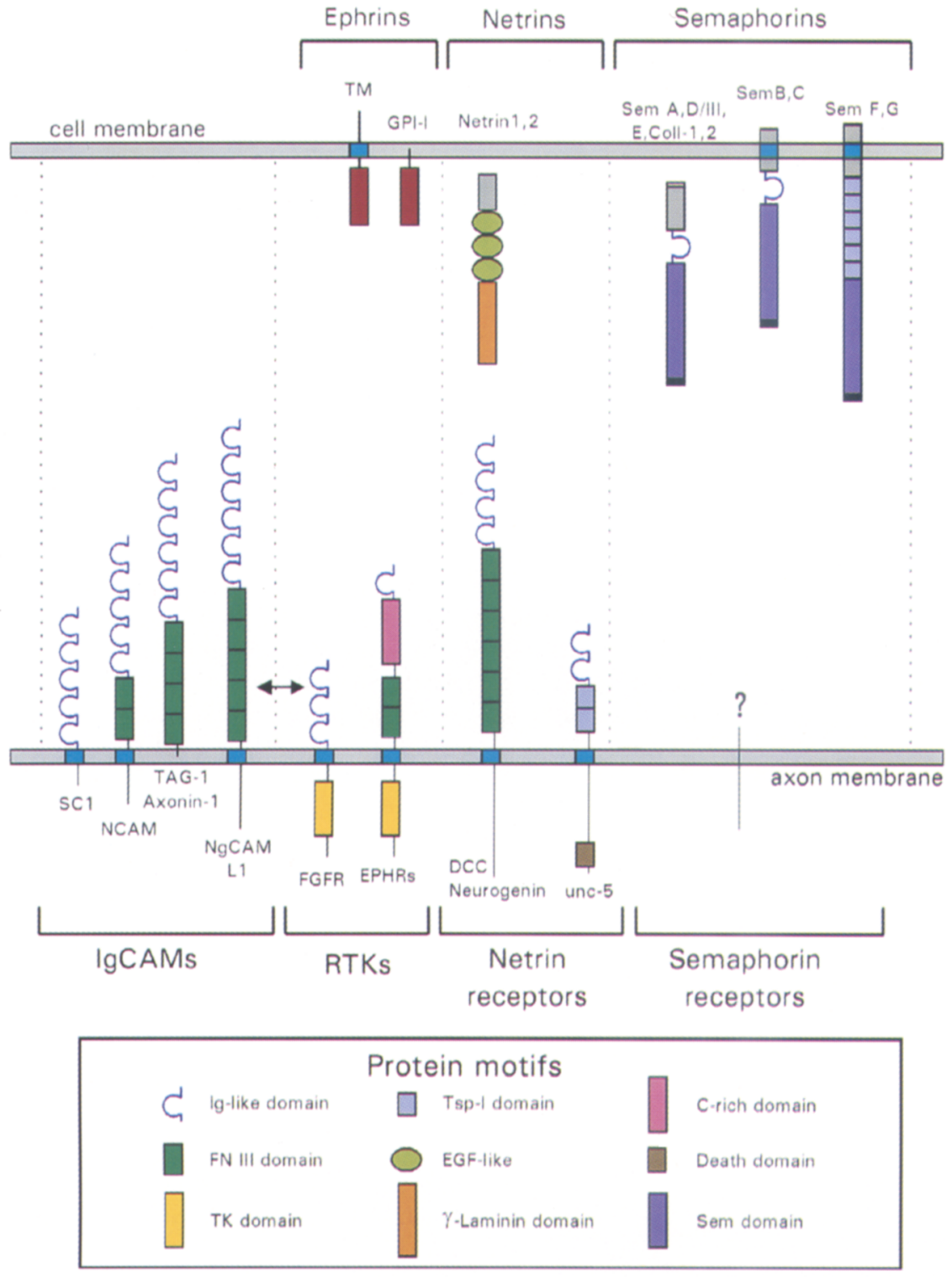

Figure 2. Axon guidance molecules and their receptors. Members of the different families of proteins with potential roles in axon guidance are shown. These may be membrane-bound such as the ephrins (Eph receptor ligands), secreted proteins such as netrins and some semaphorins fonly three of five classes of semaphorins are shown), or ECM proteins such as tenascin and thrombospondin (not shown). Molecules that act as receptors for guidance molecules are shown on the axon membrane. The immunoglubulin cell adhesion molecules (IgCAMs) are capable of homophilic binding although most can bind heterophilically to other IgCAMs. The receptor tyrosine kinases (RTKs) include FGF receptor (FGFR) and Eph receptors (EPHRs). Interactions between receptors belonging to different families is exemplified by the involvement of FGFR in axon outgrowth elicited by NCAM, L1, and N-cadherin (double arrrowhead line between LI and FGFR; see text). Protein motifs found in other extracellular proteins are indicated. They include Immunoglobulin (Ig)-like, fibronectin type III (FN III), thrombospondin-1 (Tsp-1), and epidermal growth factor (EGF)-like domains. Other protein motifs include the semaphorin (Sem) domain and the protein tyrosine kinase (TK) domains.
1993). Since that time, at least seven members of the semaphorin family have been identified, some of which have direct homologs in chick, mouse, and human (Luo et al. 1995; Püschel et al. 1995; Adams et al. 1996).

A possible in vivo role for collapsin-1 and its mammalian homolog sem $D /$ sema $I I I$ was suggested by its prominent expression in the ventral part of the embryonic spinal cord (Luo et al. 1995; Messersmith et al. 1995; Püschel et al. 1995). A previous study had shown the repulsion of a subset of dorsal root ganglia (DRG) primary sensory axons by explants of ventral spinal cord in collagen gel cocultures (Fitzgerald et al. 1993). The ventral distribution of sem D/sema III raised the possibility of its role in the termination patterns of these sensory afferents. DRGs contain several classes of primary sensory neurons that can be distinguished on the basis of their physiological properties, the diameter of their axons, and their target specificity. For example, the axons of small diameter afferents involved in thermoreception and nociception terminate in laminae I and II of the dorsal horn. By contrast, the axons of the Ia afferents that mediate monosynaptic reflexes terminate on motor neurons in the ventral spinal cord. These classes of sensory neurons can also be distinguished in vitro by means of their differential response to neurotrophins. Nerve growth factor (NGF) and neurotrophin-3 (NT-3) elicit axon outgrowth of small diameter afferents and Ia afferents respectively from rat E14-15 DRGs (for review, see Messersmith et al. 1995). When these different subpopulations were maintained by culture with the appropriate factor, only the NGF-responsive axons were repelled by explants of ventral spinal cord in collagen gel cultures (Messersmith et al. 1995), consistent with the fact that NGF was used in previous experiments (Fitzgerald et al. 
1993). Moreover, NGF-responsive but not NT-3-responsive DRG axons ones were repelled at a distance from sema III/sem D-secreting cell clusters (Fig. 2; Messersmith et al. 1995). This suggests a mechanism by which a chemorepellent molecule expressed ventrally governs regional termination of sensory axon subsets in the spinal cord, by inhibiting the outgrowth of axons that terminate dorsally and permitting the projection of those that terminate in the ventral horn (Fig. 3A). This model may also necessitate a signal that attracts Ia afferents to the ventral neural tube.

Targeted deletion of the sema III/sem D gene in mice has also provided evidence consistent with a role of sem $\mathrm{D} / \mathrm{III}$ in axonal guidance in vivo. Many of the axon terminals of the NGF-responsive DRG neurons, which are concentrated in the dorsal laminae of spinal cord in wildtype embryos, are calcitonin-gene-related peptide (CRGP)immunoreactive. In the sema III homozygous mutant embryos, CGRP-immunoreactive axons misproject outside their normal terminal zone and often reach the medial ventral cord and central canal (Behar et al. 1996). Sema III/sem $\mathrm{D}$ and its close relative sem $\mathrm{E}$ also repel sympathetic axons (Püschel et al. 1995; R. Adams and A. Püschel, pers. comm.). It is possible that the ventral spinal cord also rep- resents the relevant source of sema $\mathrm{III} / \mathrm{sem} \mathrm{D}$ for these axons.

Ventral spinal cord explants that include the floor plate also have a chemorepellent influence on motor axons (Guthrie and Pini 1995). Sema III/sem D is therefore a candidate chemorepellent for this neuronal type. With the exception of the oculomotor nucleus, all cranial and spinal motor axons are repelled by sema III/sem $\mathrm{D}$ in explant cocultures (Varela-Echavarría et al. 1997). This includes motor neuron subsets with both ventrally and dorsally projecting axons. At times when motor neurons first begin to project their axons, sema III/sem $D$ expression is found in part of the ventral hindbrain and spinal cord (Messersmith et al. 1995; Püschel et al. 1995; Varela-Echavarría et al. 1997). It is therefore plausible that sema III/sem D affects the early pathway decisions of subsets of motor axons by causing them to steer away from the midline (Fig. 3B).

The presence of a specific receptor for sema III/sem D-responsive growth cones can be proposed as part of the chemorepulsion response pathway. Upon binding of the receptor, sema III/sem D would initiate the signalling process that leads to changes in the cytoskeletal elements and results in the axon collapse or its steering

\section{A. DRG sensory axons}

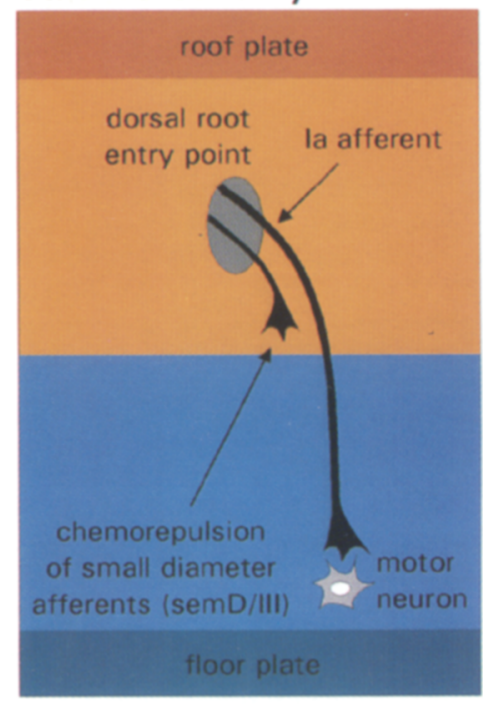

\section{B. Motor neurons}

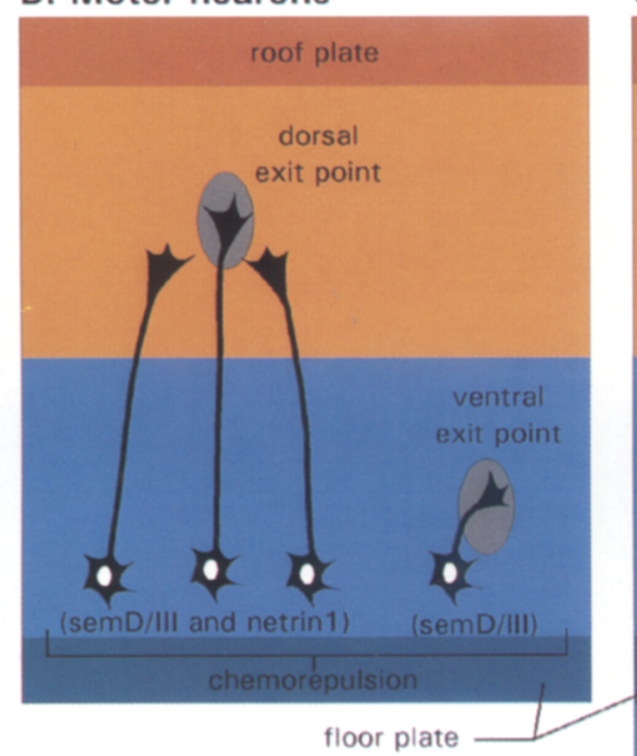

\section{Commissural neurons}

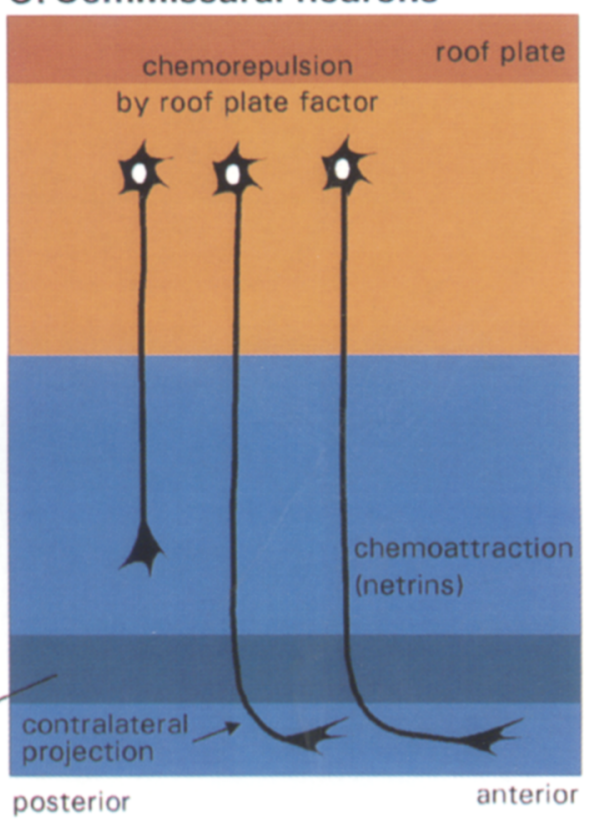

Figure 3. Determination of axonal pathways of different types of neurons by guidance molecules. Depicted are models derived from both in situ and in vivo experiments that illustrate the modes in which some guidance molecules may determine axonal pathways in vivo. Each panel represents one half of an open-book preparation of the neural tube. Dorsal is at the top and ventral at the bottom. $(A)$ The different types of DRG sensory axons respond selectively to sem D/III. The small diameter sensory afferents (NT-3-responsive) which terminate in the dorsal spinal cord are repelled by sem D/III while the Ia afferents (NGF-responsive) are unresponsive to it and project ventrally to synapse on motor neurons. $(B)$ Motor axons with dorsal exit points (e.g. cranial branchiomotor and visceral motor) are chemorepelled both by netrin-1 and sem D/III while those with ventral exit points (e.g. spinal and cranial somatic motor) respond to sem D/III only. (C) The initial ventral projection of commissural neurons is probably the result of the combined effect of a chemorepellent signal emanating from the roof plate and ventral chemoattractant signals (e.g. netrin-1 and netrin-2). After projection across the floor plate, commissural axons turn rostrally (the light blue area below the floor plate represents the contralateral basal plate). Axonin-1 and NgCAM have been implicated in this contralateral projection: additional signals are probably required to guide the axons rostrally. 
away from the source of the chemorepulsive molecule. Even though a sema III/sem D receptor has not been identified, some predictions for its properties have been made based on putative intracellular components of the collapsin response system. A cDNA has been isolated from a chick DRG cDNA library by the ability of its product to mediate collapsin-induced current response in Xenopus laevis oocytes (collapsin response mediator protein; CRMP-62; Goshima et al. 1995). CRMP-62, which is related to the Caenorhabditis elegans axon guidance-associated protein unc-33, is expressed in E7 chick embryos in the spinal cord and DRGs and appears to be involved in the collapsin-induced DRG growth cone collapse (Goshima et al. 1995). CRMP-62 may act upstream of G-proteins in the growth cone response to collapsin. Because G-proteins generally interact directly with receptors that contain seven transmembrane-spanning domains it is possible that the collapsin receptor is a protein with this structure.

Collapsin and sema III/sem D have so far been associated with inhibition or deflection of axonal outgrowth during CNS development, but a chemoattractant role for semaphorins remains a possibility. The identification of other members of the semaphorin family with expression in the CNS provides more candidate molecules with axon guidance properties. Moreover, their domains of expression during development also suggest a potential role in the guidance of axons to their peripheral targets. For example, sem D and $\mathrm{F}$ are expressed in distinct domains of the developing branchial arches and limb buds (Adams et al. 1996).

\section{Netrins and their receptors}

Netrins are a group of secreted molecules related to the ECM protein laminin; netrin homologs have been described in nematodes, insects, and vertebrates (Ishii et al. 1992; Serafini et al. 1994; Harris et al. 1996; Mitchell et al. 1996). An astonishing conservation of function has been discovered for the netrin homologs in insects, nematodes, and vertebrates (for review, see Tessier-Lavigne and Goodman 1996). The search for netrins in vertebrates was initiated following coculture experiments that demonstrated a chemoattractant effect of the floor plate on developing commissural axons (Tessier-Lavigne et al. 1988; Placzek et al. 1990). Netrins were isolated from embryonic chick brains based on their ability to elicit outgrowth of commissural axons which grow from the dorsal spinal cord ventrally to cross the floor plate (Serafini et al. 1994). In the chick embryo, netrin-1 and netrin-2 are expressed in embryonic floor plate and ventral neural tube, respectively (Kennedy et al. 1994). In addition to their outgrowth-promoting abilities, netrins chemoattract commissural axons in collagen gel cultures (Kennedy et al. 1994). Conversely, subpopulations of dorsally-projecting hindbrain motor axons including trochlear motor axons are repelled by netrin-1 (Colamarino and Tessier-Lavigne 1995; Varela-Echavarría et al. 1997). Thus, in vitro responses to netrin-1 parallel the in vivo axonal projection: netrin-1 induces oriented out- growth from dorsal neurons with ventral projections and chemorepels ventral neurons that grow dorsally (Fig. 3B and $3 \mathrm{Cl}$. In the mouse, the expression pattern of netrin-1 represents the sum of the expression patterns of netrin-1 and netrin-2 in the chick. The production of a hypomorphic allele in mice that almost completely abolishes netrin-1 expression has provided insights into the functioning of netrin-1 in vivo (Serafini et al. 1997). In these homozygous embryos most commissural axons fail to reach the ventral midline, and instead divert along ectopic routes. Consistent with this, culture experiments showed that netrin-deficient floor plates fail to elicit commissural axon outgrowth although they retain chemoattractant properties. The neurons of the trochlear nucleus, which exhibit chemorepulsion by netrin-1 in vitro, seem remarkably normal in the netrin-deficient animals, extending dorsally to form an apparently normal projection. This is mirrored in the persistence of chemorepulsion of these neurons by the mutant floor plates. However, the most dramatic phenotypes in the mutants involve the corpus callosum and the anterior commissure, which fail to form (Serafini et al. 1997). These perturbations of commissure formation in the spinal cord and brain show a profound influence of netrin on the axon pathfinding at the midline. Some residual wild-type netrin transcripts were detected in the mutant animals, complicating the interpretation of persistent axon-orienting properties of the floor plate. Nevertheless, the lack of a trochlear phenotype combined with the initially ventral projection of commissural neurons and their continuing chemoattraction to mutant floor plates may indicate the existence of guidance mechanisms working in concert with netrin-1.

In the nematode C. elegans, mutants for the netrin homolog unc-6 show defects in both dorsal and ventral axonal projections, indicating a conserved role of netrin in worms and in vertebrates (Hedgecock et al. 1990; Ishii et al. 1992). Receptors for netrin-l have been identified in vertebrates by homology searches using the sequences of unc-40 and unc-5, which encode putative receptors for the chemoattractant and chemorepellent effects of unc6 , respectively. DCC (deleted in colorectal cancer; Fearon et al. 1990) and neogenin (Vielmetter et al. 1994) were found to be homologous to unc-40. DCC and neogenin are related membrane proteins that contain immunoglobulin and fibronectin type III repeats and are members of the immunoglobulin superfamily. The finding that cells expressing DCC or neogenin bind netrin-1 protein in vitro supports the idea that DCC and neogenin are netrin receptors (Keino-Masu et al. 1996). Moreover, $\mathrm{DCC}$ is expressed in the dorsal spinal cord in the region containing commissural neurons that are responsive to netrin, and immunohistochemistry shows the protein to be present on commissural axons and growth cones. Functional evidence for the role of DCC comes from experiments in which netrin- 1 or floor plate-dependent commissural axon outgrowth in vitro was blocked by antibodies raised against the extracellular domain of DCC (Keino-Masu et al. 1996). However, application of anti-DCC antibodies in this culture system did not ab- 
rogate the chemoattractant effect of the floor plate. This observation could either reflect lack of penetration of antibodies into the explants, or could imply the action of other DCC-independent pathways. Additional roles for DCC are suggested by its expression in other neuronal cell types including some that are not responsive to netrin-1, such as spinal motor neurons.

The cloning of vertebrate homologs of unc-5, the putative receptor that mediates the repulsive activities of netrin, has recently been reported (L. Hinck, E.D. Leonardo, M. Masu, K. Keino-Masu, T. Serafini, and M. Tessier-Lavigne, pers. comm.). The members of this family of proteins contain two extracellular immunoglobulin-like and two thrombospondin type 1 repeats. Their characterization and a detailed analysis of their expression will provide useful information for the understanding of the netrin- 1 induced axon repulsion. The presence in unc-5 of a death domain (DD; Hofmann and Tschopp 1995 ) could also provide a means for the identification of intracellular proteins involved in the transduction of the signals initiated by binding of netrin to its receptor. The DD motif is present in apoptosis-associated and cytoskeletal proteins and mediates protein-protein interactions through homophilic DD-DD binding. Potential partners for unc-5-related proteins are then DD-containing proteins such as p75 NGF-R and ankyrin, a cytoskeletal protein with homology to the $C$. elegans axon guidance-associated protein unc-44 (for review, see Hofmann and Tschopp 1995).

\section{The Eph-related receptor tyrosine kinases}

The extended family of receptor tyrosine kinases includes the FGF receptors and the Trk neurotrophin receptors. The Eph-related receptor group was named based on the erythropoietin-producing hepatocellular receptor and is a growing family with at least 13 distinct members (Tuzi and Gullick 1994; Friedman and O'Leary 1996). Receptor structure includes an extracellular ligand-binding domain with an immunoglobulin-like motif, a cysteine rich region, two fibronectin type III repeats, a transmembrane domain, and an intracellular tyrosine kinase domain. Eph receptors can be further divided into two subfamilies based on their ability to bind either transmembrane or glycosyl-phosphatidylinositol (GPI)-anchored ligands (Davis et al. 1994; Gale et al. 1996). A prerequisite for receptor activation and downstream sequelae is that ligands are membrane bound or clustered; soluble ligands are not effective in signaling and can be used as blocking agents (Davis et al. 1994). Signaling via transmembrane ligands may act in both directions, presumably with ligands localized to axons and receptors in their environment. Confronting cells expressing two transmembrane ligands with the clustered extracellular domain of the Nuk receptor causes the ligands to be phosphorylated on tyrosine (Holland et al. 1996).

A bewildering array of localization patterns for Ephrelated receptors and their ligands have been reported in human, rat, mouse, chicken, frog, and zebrafish (for re- view, see Friedman and O'Leary 1996). Reagents combining receptor or ligand extracellular domains with the Fc portion of human IgG have been used to localize adjacent but nonoverlapping domains of receptors and their corresponding ligands in the mouse embryo /Gale et al. 1996). This may imply signaling at the interfaces of adjacent territories of cells in the developing embryo. Indeed, studies on the hindbrain show that Eph receptors Sek1-4 are expressed in specific rhombomeres/GilardiHebenstreit et al. 1992; Nieto et al. 1992; Becker et al. 1994). Experiments in which a truncated form of Sekl is expressed in zebrafish and Xenopus embryos show abnormal hindbrain segmentation to result (Xu et al. 1995). Eph receptor-ligand interactions are also implicated in segregating streams of cranial neural crest in Xenopus embryos and ensuring their migration into the correct branchial arch (D. Wilkinson, pers. comm.).

Persuasive evidence for the role of Eph receptors in axon guidance has come from studies on the retinotectal system. Wiring patterns of retinal axons to the optic tectum involve the projection of nasal retinal axons to the posterior tectum and temporal retinal axons to the anterior tectum. To investigate the basis of this behavior, "stripe assay" experiments were used in which membrane fragments were prepared from tissue homogenates of anterior or posterior tectum. Membrane carpets were then presented as alternating stripes of anterior or posterior tectum on a filter and strips from different regions of the retina were explanted on the carpets perpendicular to the stripes. Under these conditions, axons that display a preference for a particular substratum will be seen to grow predominantly on stripes derived from one source. The results of these experiments showed that nasal axons grew equally well on each substratum, but temporal axons grew preferentially on the anterior membranes (Walter et al. 1987). Cleaving off GPI-linked molecules using phosphatidyl inositol-specific phospholipase C (PI-PLC) reinstated the ability of temporal axons to grow on posterior substrates, and pointed to a repulsive property of the posterior tectum. Candidates for this repulsive activity have now been identified in two GPIanchored Eph ligands, RAGS and Elf-1, which were isolated in the chick and the mouse, respectively, and which are distributed throughout the optic tectum in a gradient with the highest concentration posteriorly (Cheng et al. 1995; Drescher et al. 1995). RAGS shows more restriction to the posterior part of the tectum and also a slightly steeper gradient than Elf-1. Among the receptors capable of binding these ligands is cek4, whose mouse homolog mek 4 is expressed in a gradient within the retina with high concentrations of ligand present in posterior regions. This implies that retinal ganglion cells containing high levels of receptor connect with tectal regions containing low levels of ligand, and vice versa. This has led to the proposal of a set point model in which axons with a particular concentration of receptor seek out tectal regions bearing a particular concentration of ligand (Cheng et al. 1995). How this mechanism would operate is unclear as it seems likely that purely repulsive interactions could account for the connectivity pattern. 
Others have proposed that a corresponding gradient of chemoattractant with the same polarity is required to drive axons to the correct location, but the identity of this molecular signal is unknown. A gradient of the Engrailed protein, which is expressed at high levels in the posterior tectum appears to determine the localization of RAGS and Elf-1 because misexpression of $E n$ in avia using retroviruses leads to ectopic activation of these genes (Logan et al. 1996). It is plausible that the same mechanism dictates the expression of other chemoattractant/ chemorepellents.

Both Elf- 1 and RAGS have demonstrable effects in repelling temporal axons. Misexpression of Elf-1 in the chick tectum in a mosaic fashion using retroviruses causes avoidance of ectopic Elf-1-positive patches by temporal axons (Nakamoto et al. 1996). When membranes from untransfected or RAGS-transfected cells were alternated in a stripe assay, both temporal and nasal axons were repelled, but temporal axons showed a more pronounced response (Drescher et al. 1995; U. Drescher, pers. comm.). In similar assays, Elf-1 repels only posterior axons in the same manner as posterior tectal membranes (Nakamoto et al. 1996; U. Drescher, pers. comm.). These findings point to possible differences in the mode of action of RAGS and Elf-1, because although the former might be expected to influence connectivity within the posterior tectum, the latter might be implicated in excluding temporal axons from this region. Whether separate molecular cues direct connections within the anterior tectum remains unknown. A repulsive or inhibitory effect of RAGS is emphasized by experiments on the human homolog of RAGS, AL-1. Expressed on astrocytes, AL-1 can bind the Rek-7 receptor on cortical neurons. Disruption of these interactions between cortical neurons and their astrocyte substratum leads to axon defasciculation (Winslow et al. 1995), implying that axon fasciculation is enhanced under normal circumstances by repulsive interactions with AL-1. As chick retinal axons have also been shown to express the Rek-7 homo$\log$ Cek-7, the possibility remains of a similar interaction in retinotectal development. AL-1 is also expressed at higher levels in cervical than in trunk and hindlimb muscles in the mouse, and when presented as a monolayer of transfected cells, is inhibitory for sensory and spinal neurons derived from lumbar but not cervical levels (Donoghue et al. 1996). This further supports a role for AL-1/RAGS in the position-specific termination of axons.

In mice that are null mutants for the Nuk/sek5 gene, the posterior tract of the anterior commissure fails to form (Henkemeyer et al. 1996). Rather than extending across the midline, axons grow aberrantly into the ventral floor of the forebrain. Nuk was not found to be expressed in the axons of the anterior commissure, although Nuk-expressing cells were detected in the hypothalamus and preoptic area that lie ventral to this tract. The anterior and posterior tracts of the commissure both express Lerk2, a transmembrane ligand that binds Nuk, suggesting that Nuk mediates a repulsive interaction with the ligand-expressing commissural axons. In mice expressing a mutant form of Nuk that lacks the tyrosine kinase domain, commissure formation was normal, which may be consistent with a signaling pathway whereby Nuk activates Lerk2 (Holland et al. 1996). In sek4-mutant mice the corpus callosum fails to form, and in Nuk/sek4 double mutants both commissural defects were more severe, indicating a cooperative function of these two receptors (Orioli et al. 1996). As with $\mathrm{Nuk}$, sek4 is expressed by pathway tissues and its transmembrane ligands by cortical axons. In these mutant animals, other axon pathways that express Nuk such as those of retinal ganglion cells, sensory and motor axons have not been analysed in detail, but did not show gross abnormalities.

A role for Eph-related receptors in the axon pathfinding of diverse other neuronal types including motor neurons is highly likely, based on the localization of a number of receptors to motor neuron subsets. Although Nuk is expressed globally by motor neurons (Henkemeyer et al. 1994), Cek8/Sek1 shows restricted expression by a subset of limb-innervating spinal motor neurons at brachial and lumbar levels (Ohta et al. 1996). In the rat, Tyro4 is expressed by a subset of spinal motor neurons of the medial motor column and a subset of axial muscles (Kilpatrick et al. 1996). Among cranial motor neurons, expression patterns of receptors and ligands have not been investigated. Probable Eph-mediated interactions between motor axons and peripheral structures are indicated by the localization of Eph ligands in the branchial arches (Gale et al. 1996) though none of these has yet been shown to delineate regions that are either innervated or avoided by particular motor nerves.

The existing evidence involves the Eph receptors in axon guidance as contact-dependent inhibitory signals imparted either by ligands or receptors. For example, anterior commissural axons are excluded from the hypothalamus and ventral preoptic areas of the developing brain by localized expression of Nuk receptor. Gradients of such inhibitory signals may also be responsible for more subtle effects such as the establishment of precise topographical maps in the retinotectal system. This implies more complex interactions of the growing axons with the substratum than would be expected from a purely all-or-none inhibitory signal. The expression of the various members of this family of receptors and their ligands during vertebrate development suggests more widespread roles in the guidance of CNS and PNS axons that await further study.

\section{ECM and cell adhesion molecules}

The ECM protein laminin and a number of cell adhesion molecule (CAMs) are implicated in axon guidance. Although the former is likely to act as a permissive substratum for axon elongation, the latter group of molecules have proven roles in modulating axon fasciculation and its interplay with interactions with the substratum. ECM molecules such as collagen, fibronectin, and laminin bind to cell surface receptors that may be integrins or Ig superfamily members. Laminin is 
known to promote axonal outgrowth in vitro /Gundersen 1987) and is present in some axonal pathways, notably in that of the optic tract (Cohen et al. 1987). Little evidence exists, however, to show that axons show a directional response to gradients of laminin, at least in in vitro assays (McKenna and Raper 1988). Nevertheless, laminin, a nondiffusible matrix molecule, is related to netrins, isolated on the basis of their role as diffusible chemoattractants. Possibly, a variety of axon responses to laminin-like molecules can be manifest, depending on the way in which they are presented and the receptors present on the growth cone.

Only a few examples of ECM molecules with roles in axon growth and guidance can be provided here (for review, see Hynes and Lander 1992). The recently characterized ECM protein anosmin-1 may govern the migration of precursors that form the olfactory tract, and in the axonal decussation of the corticospinal tract (SoussiYanicostas et al. 1996). Thrombospondin-1 promotes axon outgrowth in neurons from central and peripheral nervous system (Neugebauer 1991; O'Shea et al. 1991; Osterhout et al. 1992). For sympathetic neurons, this effect has been suggested to be mediated through integrin $\alpha_{3} \beta_{1}$ as a receptor on the axon membrane (DeFreitas et al. 1995). In the embryo, thrombospondin is particularily abundant in developing fiber tracts and areas of axon growth $\left\{\mathrm{O}^{\prime}\right.$ Shea and Dixit 1988), which is consistent with a role in establishing areas permissive for axon elongation.

The functions of ECM molecules may be regulated depending upon binding to proteoglycans; for example, tenascin binds to glypican, laminin to dystroglycan, and anosmin to heparin-sulfate proteoglycans. In addition, some matrix molecules may have positive and negative effects on axon outgrowth. Tenascin- $\mathrm{C}$ has both axon outgrowth-promoting and anti-adhesive domains /Götz et al. 1996). Some proteoglycans have been described in regions of the developing nervous system thought to be inhibitory for axon extension, for example keratin sulfate proteoglycan is localized in the roof plate of the spinal cord (Snow et al. 1990) and barrier tissues of the spinal motor pathway contain chondroitin sulfate proteoglycans (CSPGs; Oakley and Tosney 1991). However, CSPGs also occur in regions permissive for axon growth, such as the subplate of the developing cortex (Bicknese et al. 1994) and rhombomere boundaries (Heyman et al. 1995). These differences may relate to the heterogeneity of proteoglycans (for review, see Letourneau et al. 1994) which may vary both in the structure of their core proteins and in the diversity of their glycosaminoglycans side chains, as well as in their tendency to bind to other molecules.

The large immunoglobulin superfamily encompasses molecules that contain tandem immunoglobulin domains in their extracellular regions. Subgroups within the immunoglobulin superfamily includes the RTKs and phosphatases, netrin receptors, and CAMs. This latter group contains the neural CAM (NCAM), in addition to L1/NgCAM, NrCAM, SC1, and TAG-1/axonin-1. NCAM and the $\mathrm{N}$-cadherins constitute calcium-independent and calcium-dependent adhesion systems, respectively, in which molecules on adjacent cells bind homophilically. Isoforms of NCAM have been implicated in a number of events in axon growth and guidance /see below) whereas $\mathrm{N}$-cadherin appears to be required for retinal axon outgrowth in vivo (Riehl et al. 1996). Of the immunoglobulin superfamily, some members can also bind heterophilically to other family members or to ECM proteins, for example Ll and axonin-1 associate with one another. Elegant studies on the role of immunoglobulin superfamily members include those on commissural axon routing across the floor plate within the CNS and in the navigation of motor axons into the muscle target field of the limb bud. Commissural axons express NgCAM and axonin-1 both during their trajectory to the floor plate and having crossed it, whereas the floor plate expresses NrCAM. In vivo injections into chick embryos of anti-axonin antibodies or of soluble axonin- 1 as a blocking agent resulted in defasciculation of commissural axons and pathfinding errors such that some axons failed to decussate and instead grew along the ipsilateral floor plate border (Stoeckli and Landmesser 1995). Similar injections of antibodies to $\mathrm{Ng}$ CAM resulted in axon defasciculation but axons still crossed the floor plate correctly. Injections of antibodies to NrCAM led to pathfinding defects similar to those seen following perturbations of axonin-1. This implies that interactions between axonin-1 and NrCAM are involved in the entry of commissural axons into the floor plate, but also raise the possibility that interfering with axon-axon interactions mediated by axonin alters growth cone responses to guidance cues.

The navigation of motor axons from the neural tube into the periphery has proved an interesting system for studying the function of cell adhesion and other molecules in axon guidance. Motor axons initially grow via the anterior sclerotome, due to repulsive interactions with posterior sclerotome cells (for review, see Keynes et al. 1991). Peanut agglutinin (PNA)-binding proteins and $\mathrm{T}$-cadherin have been linked with the posterior sclerotome repulsive factor (Davies et al. 1990; Fredette and Ranscht 1994). The latter is expressed on motor axons and the posterior sclerotome, suggesting a repulsive interaction. Polysialic acid (PSA) associated with NCAM is involved in modulating interactions between axons, both those mediated by NCAM and by other molecules. The effect of removing PSA was tested in the plexus region where motor axons rearrange before entering the limb bud of the chick embryo. PSA was found to be present at low levels in regions where axons were tightly fasciculated before reaching the plexus, but to be abundant in regions of defasciculation. Specific removal of polysialic acid by application of the enzyme endoN resulted in axons with straighter and less complex trajectories (Tang et al. 1992; 1994). The effect of endoN on axon pathfinding was reversed by treatment with antibodies against $\mathrm{L} 1$ but not by those against NCAM, implicating L1-mediated interactions in the normal fasciculation process at the plexus (Tang et al. 1994). The balance of interactions mediated by NCAM and L1 is 
also involved in regulating patterns of nerve branching to fast and slow regions of embryonic muscle (Landmesser et al. 1988).

Another IgCAM family member, SC1/DM-GRASP/ BEN (Tanaka and Obata 1984; Pourquiè et al. 1990; Burns et al. 1991) is expressed on motor neurons and on a number of early axon tracts in the developing chick embryo (Chédotal et al. 1995). SC1 is present on axons extending across virgin territory (Chédotal et al. 1995), implicating it as a molecule acting during early guidance, but it is also capable of mediating homophilic binding, raising the possibility of a role in axonal fasciculation (Burns et al. 1991). In the developing cranial region, SC1 is expressed on successive cohorts of developing motor axons and in the branchial muscles they will innervate, but is down regulated once axons reach the muscle and fan out on to its surface (Simon et al. 1994), perhaps implying a requirement for $\mathrm{SC} 1$ function in motor axon-muscle interaction. SCl may also mediate recognition between axons and their targets based on expression of SC1 in the olivocerebellar pathway (Chédotal et al. 1996). SCl is thus implicated in both axon-axon and axon-target interactions, although critical experiments that involve blocking $\mathrm{SCl}$ function to test its role are as yet lacking. Recently, binding of SCl to $\mathrm{Ll} / \mathrm{Ng}$ CAM has been demonstrated, with antibodies to SC1 capable of blocking axon extension on an L1/NgCAM substratum (DeBernardo and Chang 1996), though it is not clear whether this interaction occurs within the plane of the membrane or between adjacent cells. Given that $\mathrm{Ll} / \mathrm{NgCAM}$ may display heterophilic interactions with a number of other cell surface molecules, SC1 may have a more far-reaching influence over interactions mediated by members of the immunoglobulin superfamily.

\section{Signal transduction pathways in growth cone motility}

Only scanty information exists with relevance to signal transduction pathways activated by the axon guidance molecules. One of the challenges now is to integrate the action of these factors and the physiological changes in the axon that are translated into stereotypical axonal responses. How signals are transduced via the netrin receptor DCC, whose cytoplasmic domain lacks recognizable motifs, is unknown. However, in the case of tyrosine kinase receptors such as the Eph family, tyrosine phosphorylation is likely to be the crucial event evoking downstream consequences. The FGF receptor (FGFR) also possesses tyrosine kinase domains, and has been involved in the axonal growth induced by the cell adhesion molecules NCAM, N-cadherin, and L1/NgCAM (for review, see Doherty and Walsh 1996). These CAMs stimulate neurite outgrowth by activating the FGFR. Direct interaction between FGFR and the CAMs has been suggested to involve a 20-amino acid stretch in the FGFR (CAM-homology domain) and similar sequences found in the CAMs. Activated FGFR triggers a second-messenger system involving tyrosine phosphorylation and increased calcium influx into the neurons. This ultimately leads to the activation of calcium/calmodulin-depen- dent kinase, which may in turn be responsible for the phosphorylation of proteins required for axon motility. A role for FGFR signalling in axon pathfinding is also indicated by experiments done in the developing Xenopus visual system (McFarlane et al. 1995). FGFR is present on the growth cones of the retinal ganglion neurons and bFGF induces outgrowth of retinal axons in vitro. Exogenously applied bFGF in exposed brain preparations caused misprojection of retinal axons upon their arrival at the tectal border. Possible involvement of CAMs in this process was not analyzed. Other nonreceptor protein tyrosine kinases have also been implicated in modulating neurite outgrowth stimulated by CAMs. pp $60^{\mathrm{c}-\mathrm{src}}$ and pp $59^{\text {fyn }}$ have been proposed as components of the L1 and NCAM signaling pathways respectively (Beggs et al. 1994; Ignelzi et al. 1994). Furthermore, the protein kinase $\mathrm{p} 90^{\text {rsk }}$ can phosphorylate $\mathrm{L} 1$ and has been found as part of a complex including $\mathrm{L} l$ in brain extracts, but the relevance of this interaction for $\mathrm{L} 1$ function has not been determined (Wong et al. 1996).

Growth cone pathfinding depends upon the reorganization of the cytoskeleton in response to nonuniformly distributed guidance cues. Strongly implicated in regulating the structure of the cytoskeleton are the Rho family of small GTP-binding proteins, which includes Rho, $\mathrm{Rac}$, and $\mathrm{Cdc} 42$. These factors modulate the arrangement of the actin cytoskeleton in a specific manner and have differential effects on the exploratory strucures of the growth cone, the filopodia and lamellipodia. Whereas Rho regulates actin stress fiber formation and focal adhesion, Racl regulates lamellipodial formation, and Cdc42 the formation of filopodia (e.g., Ridley and Hall 1992; Nobes and Hall 1996). Such reorganization of the cytoskeleton has been demonstrated in cultured cells by microinjection of the purified proteins (for review, see Luo et al. 1997). An in vivo role for these factors is suggested by studies of Drosophila homologs of Rac1 and $\mathrm{Cdc} 42$, in which expression of consititutively active or dominant-negative forms of the proteins caused defects in axon outgrowth, and loss of Cdc42 function affected dendrite formation (Luo et al. 1994). In the mouse, expression of the activated form of Racl produced cerebellar defects involving loss of presynaptic terminals from Purkinje cells, consistent with the observed effects in Drosophila (Luo et al. 1996).

The steps whereby signals impinging on the growth cone regulate the activity of small GTP-binding proteins is uncertain, but transduction of signals via tyrosine kinase receptors may employ adapter proteins containing $\mathrm{SH} 2$ domains. These in turn act on two classes of factors that regulate the activity of GTP-binding proteins (i.e. guanine nucleotide exchange factors and GTPase-activating proteins; for review, see Luo et al. 1997). A number of potential effector molecules have recently been identified, including the WASP protein, which is capable of binding the GTP-bound form of Cdc42 and induces actin polymerization when expressed in cultured cells (Symons et al. 1996). F-actin distribution appears to be the crucial determinant of growth cone steering in reponse to these effector proteins (for review, see Bentley 
and O'Connor 1994). Alterations in the pattern of actin microfilaments lead to consolidation of microtubules in one region of the growth cone, resulting in turning.

\section{Concerted action of guidance molecules on axonal responses}

How can the effects of different axon guidance molecules be integrated? Although they are so many, these guidance molecules have common features. They include diffusible molecules (e.g., netrins and semaphorins), membrane-bound molecules (e.g., semaphorins, Eph receptors and their ligands, and CAMs) and ECM proteins (e.g., tenascin and laminin). Membrane-bound and diffusible proteins possess modular design with known extracellular protein motifs as building blocks. Fibronectin, immunoglobulin, laminin, and thrombospondin motifs are among the structural elements that constitute both ligands and their receptors, although other novel protein motifs have functions which are as yet undetermined.

Axon guidance molecules may reach growth cones via diffusion from the target or by direct contact with the surfaces of adjacent cells. But despite the fact that the site of synthesis of guidance molecules may differ, an axon ultimately responds only to cues present in the substratum it traverses. Moreover, diffusible molecules may become bound to cell surfaces secondarily and be presented to the axons in a way that resembles the way local, nondiffusible cues are displayed. The axons may therefore respond to guidance cues that are presented in a similar way depending on the repertoire of receptors expressed. And because there appear to be few alternatives for the growing axon in response to exogenous cues, it is likely that the axon processes elicited by guidance molecules converge on some of the intracellular elements that control cytoskeletal reorganization during axon growth and pathfinding.

The spectrum of axon responses encompass arrest of growth or continuing growth. Arrest of growth may be transient or result in growth cone collapse and/or axonal retraction. Continued growth may be in the same direction or involve altering direction of growth or branching. Branching may be followed by conversion of one of the branches into the main axon and retraction of the other branches. Guidance cues may also elicit collateral branching from the primary axon rather than eliciting a response from the growth cone. Thus, a theoretical binary code could be made that defines the axon pathway of each neuron by coding the dichotomic decisions made at each choice point upon encountering specific combinations of guidance cues.

Combination of antagonistic attractive and repulsive signals emanating from distant sources may impinge on the same neuronal population (Fig. 1). This may act by the provision of complementary gradients diffusing from different sources, as in the case of commissural axons whose ventral pathway is determined by netrin-1-mediated attraction from the floor plate and repelled by a diffusible signal from the roof plate /Fig. 3C; Kennedy et al. 1994; A. Augsburger, A. Schuchardt, S. Hoskins, and
J. Dodd, pers. comm.). Alternatively, these two gradients may be polarized in the same direction, as in the optic tectum, where inhibitory (RAGS and Elf-1; Drescher et al. 1995; Cheng et al. 1995) and unknown chemoattractant molecules are proposed to underlie the specificity of connections.

\section{Future prospects}

Understanding the molecular mechanisms that underlie axon guidance has gained impetus from the identification of families of guidance molecules, reflecting a limited number of receptor-ligand systems. The techniques developed to study of this generation of guidance molecules will allow the isolation and characterization of other members of the same families as well as of molecules whose existence is suspected from in vitro and in vivo assays. Genetic screens in zebrafish are also likely to gather impetus in the coming years as tools for the identification of new genes implicated in axon guidance, as well as continuing analysis of transgenic mice. The identification of receptors for guidance cues now affords possibility of unravelling the actions of diverse signals on the intracellular signal transduction pathways that influence the cytoskeleton. One of the most exciting challenges of future research will be to integrate the action of positive and negative regulators of axonal growth and pathfinding in the elaboration of a single axon pathway.

\section{Acknowledgments}

We thank Adam Hacker and Andrew Lumsden for their valuable comments on the manuscript.

\section{References}

Adams, R.H., H. Betz, and A.W. Püschel. 1996. A novel class of murine semaphorins with homology to thrombospondin is differentially expressed during early embryogenesis. Mech. Dev. 57: 33-45.

Becker, N., T. Seitanidou, P. Murphy, M.-G. Mattèi, P. Topilko, M.A. Nieto, D.G. Wilkinson, P. Charnay, and P. GilardiHebenstreit. 1994. Several receptor tyrosine kinase genes of the Eph family are segmentally expressed in the developing hindbrain. Mech. Dev. 47: 3-17.

Beggs, H.E., P. Soriano, and P.F. Maness. 1994. NCAM dependent neurite outgrowth is inhibited in neurons from fynminus mice. I. Cell Biol. 127: 825-833.

Behar, O., J.A. Golden, H. Mashimo, F.J. Schoen, and M.C. Fishman. 1996. Semaphorin III is needed for growth of nerves, bones and heart. Nature 383: 525-528.

Bentley, D. and T.P. O'Connor. 1994. Cytoskeletal events in growth cone steering. Curr. Opin. Neurobiol. 4: 43-48.

Bicknese, A.R., A.M. Sheppard, D.D.M. O'Leary, and A.L. Pearlman. 1994. Thalamocortical axons extend along a chondroitin sulfate proteoglycan-enriched pathway coincident with neocortical subplate and distinct from the efferent path. $J$. Neurosci. 14: 3500-3510.

Burns, F.R., S. von Kannen, L. Guy, J.A. Raper, J. Kamholz, and S. Chang. 1991. DM-GRASP, a novel immunoglobulin superfamily axonal surface protein that supports neurite extension. Neuron 7: 209-220. 
Chédotal, A., O. Pourquié, and C. Sotelo. 1995. Initial tract formation in the brain of the chick embryo: Selective expression of the BEN/SC1/DM-GRASP cell adhesion molecule. Eur. J. Neurosci. 7: 198-212.

Chédotal, A., O. Pourquié, F. Ezan, H. San Clemente, and C. Sotelo. 1996. BEN as a presumptive target recognition molecule during the development of the olivocerebellar system. J. Neurosci. 16: 3296-3310.

Cheng, H.J., M. Nakamoto, A.D. Bergemann, and J.G. Flanagan. 1995. Complementary gradients in expression and binding of ELF-1 and Mek4 in development of the topographic retinotectal projection map. Cell 82: 371-381.

Cohen, J., J.F. Burne, C. McKinlay, and J. Winter. 1987. The role of laminin/fibronectin receptor complex in the outgrowth of retinal ganglion cell axons. Dev. Biol. 122: 407-418.

Colamarino, S.A. and M. Tessier-Lavigne. 1995. The axonal chemoattractant netrin- 1 is also a chemorepellent for trochlea motor axons. Cell 81: 621-629.

Davies, J.A., G.M. Cook, C.D. Stern, and R.J. Keynes. 1990. Isolation from chick somites of a glycoprotein fraction that causes collapse of dorsal root ganglion growth cones. Neuron 4: $11-20$.

Davis, S., N.W. Gale, T.H. Aldrich, P.C. Maisonpierre, V. Lhotak, T. Pawson, M. Goldfarb, and G.D. Yancopoulos. 1994. Ligands for EPH-related receptor tyrosine kinases that require membrane attachment or clustering for activity. Science 266: 816-819.

DeBernardo, A.P. and S. Chang. 1996. Heterophilic interactions of DM-GRASP: GRASP-NgCAM interactions involved in neurite extension. J. Cell Biol. 133: 657-666.

DeFreitas, M.F., C.K. Yoshida, W.A. Fraizer, D.L. Mendrick, R.M. Kypta, and L.F. Reichardt. 1995. Identification of integrin $\alpha_{3} \beta_{1}$ as a neuronal thrombospondin receptor mediating neurite outgrowth. Neuron 15: 333-343.

Dodd, J. and T.M Jessell. 1988. Axon guidance and the patterning of neural projections in vertebrates. Science 242: $692-$ 699.

Doherty, P. and F.S. Walsh. 1996. CAM-FGF receptor interactions: A model for axonal growth. Mol. Cell. Neurosci. 8: 99 111.

Donoghue, M.J., R.M. Lewis, J.P. Merlie, and J.R. Sanes. 1996. The Eph kinase ligand AL-1 is expressed by rostral muscles and inhibits outgrowth from caudal neurons. Mol. Cell. Neurosci. 8: 185-198.

Drescher, U., C. Kremoser, C. Handwerker, I. Löschinger, M. Noda, and F. Bonhoeffer. 1995. In vitro guidance of retinal ganglion cell axons by RAGS, a $25 \mathrm{kDa}$ tactal protein related to ligands for Eph receptor tyrosine kinases. Cell 82: 359 370.

Fearon, E.R., K.R. Cho, J.M. Nigro, S.E. Kern, J.W. Simons, J.M. Ruppert, S.R. Hamilton, A.C. Preisinger, G. Thomas, K.W. Kinzler, and B. Vogelstein. 1990. Identification of a chromosome $18 \mathrm{q}$ gene that is altered in colorectal cancers. Science 247: 49-56.

Fitzgerald, M., G.C. Kwiat, J. Middleton, and A. Pini. 1993. Ventral spinal cord inhibition of neurite outgrowth from embryonic rat dorsal root ganglia. Development 117: 1377-1384.

Fredette, B.J. and B. Ranscht. 1994. T-cadherin expression delineates specific regions of the developing motor axon-hindlimb projection pathway. I. Neurosci. 14: 7331-7346.

Friedman, G.C. and D.D.M. O'Leary. 1996. Eph receptor tyrosine kinases and their ligands in neural development. Curr. Opin. Neurobiol. 6: 127-134.

Gale, N.W., S.J. Holland, D.M. Valenzuela, A. Flenniken, L. Pan, T. Ryan, M. Henkemeyer, K. Strebhardt, H. Hirai, D.G. Wilkinson, T. Pawson, S. Davis, and G.D. Yancopoulos.
1996. Eph receptors and ligands comprise two major specificity subclasses and are reciprocally compartmentalized during embryogensis. Neuron 17: 9-19.

Gilardi-Hebenstreit, P., M.A. Nieto, M. Frain, M.-G. Mattei, A. Chestier, D. Wilkinson, and P. Charnay. 1992. An eph-related receptor protein tyrosine kinase gene segmentally expressed in the developing mouse hindbrain. Oncogene 7: 2499-2506.

Goshima, Y., F. Nakamura, P. Strittmatter, and S.M. Strittmatter. 1995. Collapsin-induced growth cone collapse mediated by an intracellular protein related to UNC-33. Nature 376: 509-514.

Götz, B., A. Scholze, A. Clement, A. Joester, K. Schütte, F. Wigger, R. Frank, E. Spiess, P. Ekblom, and A. Faissner. 1996. Tenascin-C contains distinct adhesive, anti-adhesive, and neurite outgrowth promoting sites for neurons. I. Cell Biol. 132: 681-699.

Gundersen, R.W. 1987. Response of sensory neurites and growth cones to patterned substrata of laminin and fibronectin in vitro. Dev. Biol. 121: 423-431.

Guthrie, S. and A. Pini. 1995. Chemorepulsion of developing motor axons by the floor plate. Neuron 14: 1117-1130.

Harris, R., L.M. Sabatelly, and M.A. Seeger. 1966. Guidance cues at the Drosophila CNS midline: Identification and characterization of two Drosophila netrin/unc-6 homologs. Neuron 17: 217-228.

Hedgecock, E.M., J.G. Culotti, and D.H. Halls. 1990. The unc-5, unc- 6 and unc- 40 genes guide circumferential migrations of pioneer axons and mesodermal cells on the epidermis in $C$. elegans. Neuron 2: 61-85.

Henkemeyer, M., L.E.M. Marengere, J. McGlade, J.P. Olivier, R. Conlon, D.P. Holmyard, K. Letwin, and T. Pawson. 1994. Immunolocalization of the Nuk receptor tyrosine kinase suggests roles in segmental patterning of the brain and axonogenesis. Oncogene 9: 1001-1014.

Henkemeyer, M., D. Orioli, J. Henderson, T. Saxton, J. Roder, T. Pawson, and R. Klein. 1996. Nuk controls pathfinding of commissural axons in the mammalian central nervous system. Cell 86: 35-46.

Heyman, I., A. Faissner, and A. Lumsden. 1995. Cell and matrix specialization of rhombomere boudaries. Dev. Dynam. 204: 301-315.

Hofmann, K. and J. Tschopp. 1995. The death domain motif found in Fas (Apo-1) and TNF receptor is present in proteins involved in apoptosis and axonal guidance. FEBS Lett. 371: 321-323.

Holland, S.J., N.W. Gale, G. Mbamalu, G.D. Yancopoulos, M. Henkemeyer, and T. Pawson. 1996. Bidirectional signalling through the EPH-family receptor Nuk and its transmembrane ligands. Nature 383: 722-725.

Hynes, R.O. and A.D. Lander. 1992. Contact and adhesive specificities in the associations, migrations, and targeting of cells and axons. Cell 68: 303-322.

Ignelzi, M.A., D.R. Miller, P. Soriano, and P.F. Maness. 1994. Impaired neurite outgrowth of src-minus cerebellar neurons on the cell adhesion molecule L1. Neuron 12: 873-884.

Ishii, N., W.G. Wadsworth, B.D. Stern, J.G. Culotti, and E.M. Hedgecock. 1992. UNC-6 a laminin-related protein, guides cell and pioneer axon migrations in C. elegans. Neuron 9: $873-881$.

Keino-Masu, K., M. Masu, L. Hink, E. D. Leonardo, S. S.-Y. Chan, J. G. Culotti, and M. Tessier-Lavigne. 1996. Deleted in colorectal cancer $(D C C)$ encodes a netrin receptor. Cell 87: 175-185.

Kennedy, T.E., T. Serafini, J.R. de la Torre, and M. TessierLavigne. 1994. Netrins are diffusible chemotropic factors for 
commissural axons in the embryonic spinal cord. Cell 78: 425-435.

Keynes, R.J., K.F. Jaques, and G.M. Cook. 1991. Axon repulsion during peripheral nerve segmentation. Development (Suppl.) 2: 131-139.

Kilpatrick, T.J., A. Brown, C. Lai, M. Gassmann, M. Goulding, and G. Lemke. 1996. Expression of the Tyro4/Mek4/Cek4 gene specifically marks a subset of embryonic motor neurons and their muscle targets. Mol. Cell. Neurosci. 7: 62-74.

Kolodkin, A.L., D.J. Matthes, T.P. O'Connor, N.H. Patel, A. Admon, D. Bentley, and C.S. Goodman. 1992. Fasciclin IV: sequence, expression and function during growth cone guidance in the grasshopper embryo. Neuron 9: 831-845.

Kolodkin, A.L., D.J. Matthes, and C.S. Goodman. 1993. The semaphorin genes encode a family of transmembrane and secreted growth cone guidance molecules. Cell 75: 1389-1399.

Landmesser, L., L. Dahm, K. Schultz, and U. Rutishauser. 1988. Distinct roles for adhesion molecules during innervation of embryonic chick muscle. Dev. Biol. 130: 645-670.

Letourneau, P.C., M.L. Condic and D.M. Snow. 1994. Interactions of developing neurons with the extracellular matrix. $J$. Neurosci. 14: 915-928.

Logan, C., A. Wizenmann, U. Drescher, B. Monschau, G. Bonhoeffer, and A. Lumsden. 1996. Rostral optic tectum acquires caudal characteristics following ectopic engrailed expression. Curr. Biol. 6: 1006-1014.

Luo, L., Y.J. Liao, L.Y. Jan and Y.N. Jan. 1994. Distinct morphogenetic functions of similar small GTPases: Drosophila Drac 1 is involved in axonal outgrowth and myoblast fusion. Genes \& Dev. 8: 1787-1802.

Luo, L., T.K. Hensch, L. Ackerman, S. Barbel, L.Y. Jan and Y.-N., Jan. 1996. Differential effects of the Rac GTPase on Purkinje cell axons and dendritic trunks and spines. Nature 379: 837-840.

Luo, L., L.Y. Jan, and Y.-N. Jan. 1997. Rho family of small GTPbinding proteins in growth cone signalling. Curr Biol. 7: (in press).

Luo, Y., D. Raible, and J.A. Raper. 1993. Collapsin: A protein that induces the collapse and paralysis of a neural growth cone. Cell 75: 1389-1399.

Luo, Y., I. Shepherd, M. Li, M.J. Renzi, S. Chang, and J.A. Raper. 1995. A family of molecules related to collapsin in the embryonic chick nervous system. Neuron 14: 1131-1140.

McFarlane, S., L. McNeill, and C.E. Holt. 1995. FGF signaling and target recognition in the developing xenopus visual system. Neuron 15: 1017-1028.

McKenna, M.P. and J.A. Raper. 1988. Growth cone behavior on gradients of substratum bound laminin. Dev. Biol. 130: 232 236.

Messersmith, E.K., E.D. Leonardo, C.J. Shatz, M. Tessier-Lavigne, C.S. Goodman, and A.L. Kolodkin. 1995. Semaphorin III can function as a selective chemorepellent to pattern sensory projections in the spinal cord. Neuron 14: 949-959.

Mitchell, K.J., J.L. Doyle, T. Serafini, T.E. Kennedy, M. TessierLavigne, C.S. Goodman, and B.J. Dickson. 1996. Genetic analysis of netrin genes in Drosophila: Netrins guide CNS commissural axons and peripheral motor axons. Neuron 17: 203-215

Nakamoto, M., H.-J. Cheng, G.C. Friedman, T. McLaughlin, M.J. Hansen, C.H. Yoon, D.D.M. O'Leary, and J.G. Flanagan. 1996. Topographically specific effects of ELF-1 on retinal axon guidance in vitro and retinal axon mapping in vivo. Cell 86: $755-766$.

Neugebauer, K.M., C.J. Emmett, K.A. Venstrom, and L.F. Reichardt. 1991. Vitronectin and thrombospondin promote retinal neurite outgrowth: Developmental regulation and role of integrins. Neuron 6: 345-358.
Nieto, M.A., P. Gilardi-Hebenstreit, P. Charnay, and D.G. Wilkinson. 1992. A receptor protein tyrosine kinase implicated in the segmental patterning of the hindbrain and mesoderm. Development 116: 1137-1150.

Nobes, C.D. and A. Hall. 1995. Rho, Rac and Cdc42 GTPases regulate the assembly of multimolecular focal complexes associated with actin stress fibers, lamellipodia and filopodia. Cell 81: 53-62.

O'Shea, K.S. and V.M. Dixit. 1988. Unique distribution of the extracellular matrix component thrombospondin in the developing mouse. I. Cell Biol. 107: 2737-2748.

O'Shea, K.S., L.-H.J. Liu, and V.M. Dixit. 1991. Thrombospondin and a $140 \mathrm{kd}$ fragment promote adhesion and neurite outgrowth from embryonic central and peripheral neurons and from PC12 cells. Neuron 7: 231-237.

Oakley, R.A. and K.W. Tosney. 1991. Peanut agglutinin and chondroitin-6-sulphate are molecular markers for tissues that act as barriers to axon advance in the avian embryo. Dev. Biol. 147: 187-206.

Ohta, K., Nakamura M, K. Hirokawa, S. Tanaka, A. Iwama, T. Suda, M. Ando, and H. Tanaka. 1996. The receptor tyrosine kinase, Cek8, is transiently expressed on subtypes of motoneurons in the spinal cord during development. Mech. Dev. 54: 59-69.

Orioli, D., M. Henkemeyer, G. Lemke, R. Klein, and T. Pawson. 1996. Sek4 and Nuk receptors cooperate in guidance of commissural axons and in palate formation. EMBO J. 15: 60356049.

Osterhout, D.J., W.A. Frazier, and D. Higgins. 1992. Thrombospondin promotes process outgrowth in neurons from the peripheral and central nervous system. Dev. Biol. 150: 256265.

Placzek, M., M. Tessier-Lavigne, T.M. Jessell, and J. Dodd. 1990. Orientation of commissural axons in vitro in response to a floor plate-derived chemoattractant. Development 110: 1930.

Pourquié, O., M. Coltey, J.-L. Thomas, and N.M. Le Douarin. 1990. A widely distriuted antigen developmentally regulated in the nervous system. Development 109: 743-752.

Püschel, A.W., R.H. Adams, and H. Betz. 1995. Murine semaphorin D/collapsin is a member of a diverse gene family and creates domains inhibitory for axonal extension. Neuron 14: $941-948$.

Raper, J.A. and J.P. Kapfhammer. 1990. The enrichment of a neuronal growth cone collapsing activity from embryonic brain. Neuron 4: 21-29.

Ridley, A.J. and A. Hall. 1992. The small GTP-binding protein Rho regulates the assembly of focal adhesions and actin stress fibers in response to growth factors. Cell 70: 401-410.

Riehl, R., K. Johnson, R. Bradley, G.B. Grunwald, E. Coronel, A. Lilienbaum, and C.E. Holt. 1996. Cadherin function is required for axon outgrowth in retinal ganglion cells in vivo. Neuron 17: 837-848.

Serafini, T., T.E. Kennedy, M.J. Galko, C. Mirzayan, T.M. Jessell, and M. Tessier-Lavigne. 1994. The netrins define a family of axon outgrowth-promoting proteins homologous to C. elegans UNC-6. Cell 78: 409-424.

Serafini, T., S.A. Colamarino, E.D. Leonardo, H. Wang, R. Beddington, W.C. Skarnes, and M. Tessier-Lavigne. 1997. Netrin-1 is required for commissural axon guidance in the developing vertebrate nervous system. Cell 87: 1001-1014.

Simon, H. and A. Lumsden. 1993. Rhombomere-specific origin of the contralateral vestibulo-acoustic efferent neurons and their migration across the embryonic midline. Neuron 11: $209-220$.

Simon, H., S. Guthrie, and A. Lumsden. 1994. Regulation of 
SC1/DM-GRASP during the migration of motor neurons in the chick embryo brainstem. I. Neurobiol. 25: 1129-1143.

Snow, D.M., D.A. Steindler, and J. Silver. 1990. Molecular and cellular characterization of the glial roof plate of the spinal cord and optic tectum: A possible role for a proteoglycan in the development of an axon barrier. Dev. Biol. 138: 359-376.

Soussi-Yanicostas, N., J.-P. Hardelin, M.del M. Arroyo-Jimenez, O. Ardouin, R. Legouis, J. Levilliers, F. Traincard, J.-M. Betton, L. Cabaniè, and C. Petit. 1996. Initial characterization of anosmin-1, a putative extracellular matrix protein synthesized by definite neuronal cell populations in the central nervous system. J. Cell. Sci. 109: 1749-1757.

Stoeckli, E.T. and L.T. Landmesser. 1995. Axonin-1, Nr-CAM, and $\mathrm{Ng}$-CAM play different roles in the in vivo guidance of chick commissural neurons. Neuron 14: 1165-1179.

Symons, M., J.M. Derry, B. Karlak, S. Jiang, V. Lemanieu, F. McCormick, U. Francke, A. Abo. 1996. Wiskott-Aldrich syndrome protein, a novel effector for the GTPase Cdc42Hs is implicated in actin polymerization. Cell 84: 723-734.

Tanaka, H. and K. Obata. 1984. Development changes in unique cell surfaces antigens of chick embryo spinal motorneurons and ganglion cells. Dev. Biol. 106: 26-37.

Tang, I., L. Landmesser, and U. Rutishauser. 1992. Polysialic acid influences specific pathfinding by avian motoneurons. Neuron 8: 1031-1044.

Tang, J., U. Rutishauser, and L. Landmesser. 1994. Polysialic acid regulates growth cone behavior during sorting of motor axons in the plexus region. Neuron 13: 405-414.

Tessier-Lavigne, M. and C. Goodman. 1996. The molecular biology of axon guidance. Science 274: 1123-1133.

Tessier-Lavigne, M., M. Placzek, A.G.S. Lumsden, J. Dodd, and T.M. Jessell. 1988. Chemotropic guidance of developing axons in the mammalian central nervous system. Nature 336: 775-778.

Tuzi, N.L. and W.J. Gullick. 1994. Eph, the largest known family of putative growth factor receptors. Br. J. Cancer 69: 417-421.

Varela-Echavarría, A., A. Tucker, A.W. Püschel, and S. Guthrie. 1997. Motor axon subpopulations respond differentially to the chemorepellents netrin-1 and semaphrin D. Neuron 18: 193-207.

Vielmetter, J., J.F. Kayyem, J.M. Roman, and W.J. Dreyer. 1994. Neogenin, an avian cell surace protein expressed during terminal neuronal differentiation, is closely related to the human tumor suppressor molecule deleted in colorectal cancer. J. Cell Biol. 127: 2009-2020.

Wahl, C.M., D.M. Noden, and R. Baker. 1994. Developmental relations between sixth nerve motor neurons and their targets in the chick embryo. Dev. Dynam. 201: 191-202.

Walter, J., B. Kern-Vetis, J. Huf, B. Stolze, and F. Bonhoeffer. 1987. Recognition of position-specific properties of tectal cell membranes by retinal axons in vitro. Development 101: 685-696.

Wang, L.-C., R.A. Rachel, R.C. Marcus, and C.A. Mason. 1996. Chemosupression of retinal axon growth by the mouse optic chiasm. Neuron 17: 849-862.

Winslow, J.W., P. Moran, J. Valverde, A. Shih, J.Q. Yuan, S.C. Wong, S.P. Tsai, A. Goddard, W.J. Henzel, F. Hefti, K.D. Beck, and I.W. Caras. 1995. Cloning of AL-1, a ligand for an Eph-related tyrosine kinase receptor involved in axon bundle formation. Neuron 14: 973-981.

Wong, E.V., W. Schaefer, G. Landreth, and V. Lemmon. 1996. Involvement of $\mathrm{p} 90^{\mathrm{rsk}}$ in neurite outgrowth mediated by the cell adhesion molecule L1. J. Cell Biol. 271: 18217-18223.

Xu, Q., G. Alldus, N. Holder, and D.G. Wilkinson. 1995. Expression of truncated Sek-1 receptor tyrosine kinase disrupts the segmental restriction of gene expression in the Xenopus and zebrafish hindbrain. Development 121: 4005-4016. 


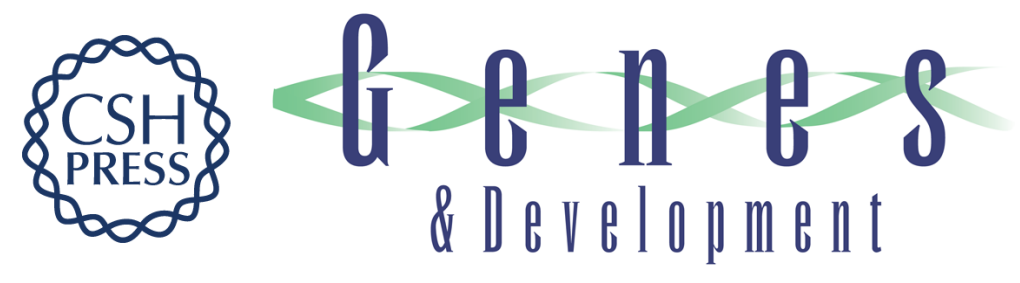

\section{Molecules making waves in axon guidance.}

A Varela-Echavarría and S Guthrie

Genes Dev. 1997, 11:

Access the most recent version at doi:10.1101/gad.11.5.545

References This article cites 95 articles, 21 of which can be accessed free at: http://genesdev.cshlp.org/content/11/5/545.full.html\#ref-list-1

License

Email Alerting Receive free email alerts when new articles cite this article - sign up in the box at the top Service right corner of the article or click here.

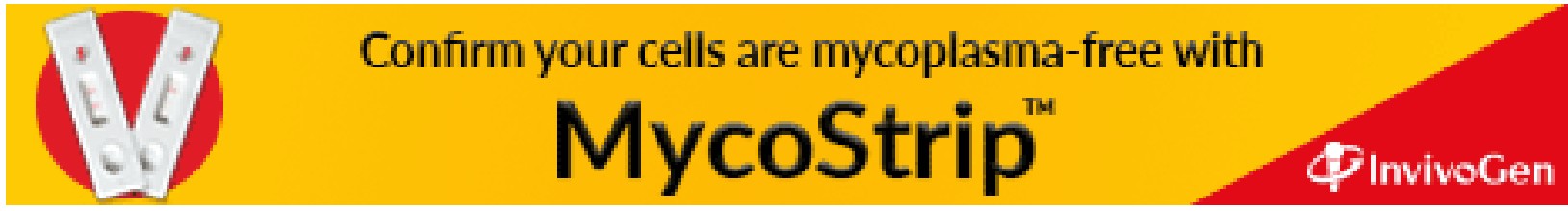

